\title{
ANÁLISE MULTITEMPORAL DO USO E OCUPAÇÃO DA TERRA E ALTERAÇÕES AMBIENTAIS NA BACIA HIDROGRÁFICA DO RIO RIBEIRÃOZINHO - MS - BRASIL
}

\author{
Adalto Moreira Braz ${ }^{1}$ \\ Karen Cristina Pereira Costa ${ }^{2}$ \\ Patricia Helena Mirandola Garcia ${ }^{3}$
}

\begin{abstract}
RESUMO
Este trabalho tem como finalidade realizar uma análise multitemporal da cobertura do uso da terra, a partir do estudo e elaboração de mapas para fins de análise e planejamento ambiental na Bacia Hidrográfica do Rio Ribeirãozinho (BHRR). A pesquisa foi realizada por meio de geotecnologias, estas que atualmente permitem retratar o ambiente em questão, de forma muito próxima da realidade encontrada no campo, fornecendo dados capazes de subsidiarem uma posterior decisão no planejamento da área. O Rio Ribeirãozinho localiza-se no município de Três Lagoas - MS. Para este trabalho foram utilizadas imagens de radar da missão Shuttle Radar Topography Mission (SRTM), imagens do satélite Landsat 5 sensor TM e Landsat 8 sensor OLI dos anos de 2010 e 2014 respectivamente. Os métodos seguidos para o mapeamento foram realizados a partir dos SIGs (Sistemas de Informações Geográficas) ArcGIS e Global Mapper. A análise ambiental realizada a partir dos mapeamentos de uso e ocupação da terra, junto à análise do relevo (imagens SRTM) proporcionaram resultados satisfatórios passíveis de serem aplicados em medidas de planejamento ambiental em bacias hidrográficas. Por fim podemos observar o aumento das áreas degradas ao longo do curso d'água na bacia, decorrente da falta de vegetação ciliar e uma grande variação da área úmida do rio, influenciada provavelmente pela maior classe de ocupação ao longo da bacia e também pela falta de vegetação.
\end{abstract}

PALAVRAS-CHAVE: Geotecnologias, Uso da Terra, Planejamento Ambiental.

\section{ANALYSIS MULTITEMPORAL USE AND OCCUPATION OF EARTH AND ENVIRONMENTAL CHANGES IN RIVER BASIN RIBEIRÃOZINHO - MS - BRAZIL}

\begin{abstract}
This work aims to perform a multi-temporal analysis of the coverage of land use, from the study and preparation of maps for analysis and environmental planning in the Basin Ribeirãozinho Rio (BHRR). The survey was conducted by geo, these currently available to portray the environment in question, very close to reality found in the form field, providing data able to subsidize a later decision in the planning area. The Ribeirãozinho Rio is located in Três Lagoas - MS. For this work, images of radar mission Shuttle Radar Topography Mission (SRTM) images of Landsat 5 TM sensor and Landsat 8 OLI sensor the years 2010 and 2014 respectively. The methods used for mapping were carried out

\footnotetext{
${ }^{1}$ Geógrafo, mestrando em Geografia pelo PPGGEO/UFMS. adaltobraz.geografia@gmail.com.

${ }^{2}$ Graduanda em Geografia Licenciatura pela UFMS/CPTL. karen_cpcosta@hotmail.com.

${ }^{3}$ Prof. ${ }^{\text {a }}$ Dra . do Programa de Pós Graduação em Geografia da UFMS/CPTL. patriciaufmsgeografia@gmail.com.
} 
from the GIS (Geographic Information Systems) ArcGIS and Global Mapper. The environmental analysis carried out on the use of mapping and land tenure, with the analysis of the relief (SRTM images) provided satisfactory results that can be applied in environmental planning measures in watersheds. Finally we can see the increase in degraded areas along the stream in the basin, due to the lack of riparian vegetation and a large variation of the wet area of the river, probably influenced by higher occupancy class along the basin and also by the lack vegetation.

KEY-WORDS: Geotechnologies, Land Use, Environmental Planning.

\title{
ANÁLISIS MULTITEMPORAL USO Y OCUPACIÓN DE LA TIERRA Y MEDIO AMBIENTE CAMBIO DE CUENCA RIBEIRÃOZINHO - MS - BRASIL
}

\section{RESUMEN}

Este trabajo tiene como objetivo realizar un análisis multitemporal de la cobertura de uso de la tierra, desde el estudio y preparación de mapas para el análisis y la planificación ambiental en la Cuenca del Río Ribeirãozinho (BHRR). La encuesta fue realizada por geo, éstos actualmente disponible para retratar el entorno en cuestión, muy cerca de la realidad que se encuentra en el campo de formulario, proporcionando datos capaces de subsidiar una decisión más adelante en el área de planificación. El Ribeirãozinho Rio está situado en Três Lagoas - MS. Para este trabajo, imágenes imágenes de Misión misión Shuttle Radar Topography radar (SRTM) de Landsat 5 TM y sensor Landsat 8 OLI sensor, el año 2010 y 2014 respectivamente. Los métodos utilizados para la cartografía se llevaron a cabo desde el SIG (Sistemas de Información Geográfica) ArcGIS y Global Mapper. El análisis ambiental realizada en el uso de la cartografía y la tenencia de la tierra, con el análisis de las imágenes de socorro (SRTM) proporcionó resultados satisfactorios que se pueden aplicar en la planificación de medidas ambientales en las cuencas hidrográficas. Por fin podemos ver el aumento de las áreas degradadas por el arroyo en la cuenca, debido a la falta de vegetación de ribera y una gran variación de la zona húmeda del río, probablemente influenciado por el aumento de la clase de ocupación a lo largo de la cuenca y también por la falta vegetación.

PALABRAS-CLAVE: Geotecnologías, Uso de la Tierra, Planificación Ambiental.

\section{INTRODUÇÃO}

A análise multitemporal do uso e ocupação da terra, no contexto do estudo em bacias hidrográficas, auxilia na compreensão da dinâmica ambiental, além de servir como importante ferramenta para o levantamento de informações, passíveis de serem usadas para o desenvolvimento de estratégias para a aplicação de um planejamento ambiental na bacia hidrográfica, além de fomentar também, o desenvolvimento de políticas públicas de gestão de bacias hidrográficas e recursos hídricos.

\begin{abstract}
O levantamento do uso da terra numa dada região tornou-se um aspecto de interesse fundamental para a compreensão dos padrões de organização do espaço. Desse modo, existe a necessidade de atualização constante dos registros de uso da terra e cobertura vegetal, para que suas tendências possam ser analisadas. Neste contexto, o sensoriamento remoto constituise em uma técnica de grande utilidade, pois permite, em curto espaço de tempo, a obtenção de informações a respeito de registros de uso da terra e cobertura vegetal (ROSA e SANO, 2014)
\end{abstract}

A escolha da Bacia Hidrográfica do Córrego Ribeirãozinho se dá devido à mesma ser uma bacia hidrográfica de pequeno porte, contando apenas com um canal fluvial 
(sem afluentes) e apesar das condições naturais favoráveis, esta bacia não possui vegetação em suas Áreas de Preservação Permanentes (APP) e no entorno de sua drenagem, e ao longo do seu canal vastas áreas degradadas, além de uma grande área assoreada em seu exutório.

Em se tratando do estudo de Bacias Hidrográficas, muito difundido na comunidade acadêmica, e atualmente se expandindo para outras comunidades, tais como empresas, ONGs, prefeituras municipais etc., Cunha e Coelho (2012) explicam como se deu a aproximação dos estudos ambientais aplicados em bacias hidrográficas, recorrendo ao tempo histórico, ressaltando que as bacias hidrográficas em geral têm sofrido várias mudanças em sua fisionomia. Com tantas mudanças e riscos ambientais, começou-se a ter uma preocupação especial com tais bacias e estudos relacionados ao planejamento de bacias hidrográficas ganham destaque entre órgãos públicos/privados, profissionais de e áreas, pessoas preocupadas com o futuro do meio ambiente etc.

No contexto de estudos ambientais aplicados em bacias hidrográficas, destacamos como parte importante a análise e monitoramento das APPs ao longo da rede de drenagem. As Áreas de Preservação Permanente (APP) estão definidas atualmente pela lei $n^{\circ} 12.651 / 2012$, e esta a define como "área protegida, coberta ou não por vegetação nativa, com a função ambiental de preservar os recursos hídricos, a paisagem, a estabilidade geológica e a biodiversidade, facilitar o fluxo gênico de fauna e flora, proteger o solo e assegurar o bem-estar das populações humanas" (BRASIL, 2012).

A mata ciliar tem algumas funções primordiais, como a função protetora (diminuindo a erosão das margens e os impactos, permite maior infiltração e a recarga de aquíferos), influencia no manejo da água dentro da bacia hidrográfica, evita o assoreamento do canal e reduz a chegada de produtos químicos, além de manter a fauna (aves e peixes) com o fornecimento de alimentos e sombra. A restauração da mata ciliar deve ser feita com diferentes espécies (floresta mista) atrativas para aves e peixes, de preferência frutíferas e de rápido crescimento (CUNHA, 2012).

A criação de APP objetiva manter inalterado o uso do solo, que deve estar coberto pela vegetação original. De maneira geral, os debates acerca da preservação e conservação da vegetação nativa merecem destaque, sobretudo aquela situada ao longo dos cursos d'água, nascentes e em regiões de topografia acidentada, sendo um dos pilares para técnicos e pesquisadores que preconizam a sua importância para proteção dos recursos hídricos. (ALMEIDA e BERGER, 2007). 
LIMA (1986) ainda ressalta o valor das APPs para uma bacia hidrográfica, reafirmando seus benefícios, como o abastecimtno contínuo do rio ou córrego com matéria orgânica de folhas, galhos e até troncos caídos, cumprindo este material orgânico uma função nutricional para a biota aquática, além de criar zonas de turbulência e velocidades diminuídas, que favorecem o processo de decomposição de partículas e sedimentos, mantendo também a própria rugosidade das margens.

Para toda esta análise ambiental da bacia hidrográfica do córrego Ribeirãozinho, assim como a distribuição espacial de sua APP e dinâmica das áreas alagadas (varjão) foi aplicado o geoprocessamento para o levantamento de informações, modelagem do cenário atual e base para as conclusões iniciais. Aliado ao geoprocessamento, utilizou-se de fotointerpretação e vetorização das imagens dos satélites Landsat 8, sensor OLI e Landsat 5, sensor TM, para o mapeamento do uso e ocupação da terra na bacia.

\begin{abstract}
Interpretar fotografias ou imagens é identificar objetos nelas representados e dar um significado a esses objetos. Assim, quando identificamos e traçamos rios e estradas, ou delimitamos uma represa, a área ou mancha urbana correspondente a uma cidade, uma área de cultivos, etc., a partir da análise de uma imagem ou fotografia, estamos fazendo sua interpretação (FLORENZANO, 2002).
\end{abstract}

Dentro deste aspecto, como bem emprega Fitz (2005), o estudo do qualquer espaço geográfico pressupõe uma série de conhecimentos e informações que podem ser trabalhadas de maneira mais ágil, fácil e rápida com as novas tecnologias. Neste aspecto, os SIGs tendem a ocupar um lugar de destaque em virtude de sua funcionalidade.

Ressaltamos que este trabalho é um dos pontos iniciais para um estudo maior, sendo este, particularmente, responsável pelo fornecimento das informações históricas da ocupação da terra nesta bacia, e da dinâmica das áreas de vegetação, úmidas e também degradadas consideradas como fatores cruciais no entendimento do aumento das erosões nesta bacias (FREIRE, 2007).

\title{
1.1. Localização geográfica da área de estudo
}

A aplicação do estudo e análise dos índices de vegetação foi aplicada na Bacia Hidrográfica do Córrego Ribeirãozinho (BHCR), inserida em sua totalidade no município de Selvíria, estado de Mato Grosso do Sul. A bacia localiza-se entre as coordenadas $20^{\circ} 23^{\prime} 48^{\prime \prime} \mathrm{S}, 52^{\circ} 3^{\prime} 16^{\prime \prime} \mathrm{W}$ e $20^{\circ} 19^{\prime} 14^{\prime \prime} \mathrm{S}, 51^{\circ} 57^{\prime}$ 8" W, e possui uma área total de $3.265,01$ ha (Figura 1). Marcada pela forte presença de campos limpos, 
convertidos em pastagem e algumas pequenas manchas de vegetação nativa e, em menor expressividade a silvicultura. Ao longo da rede de drenagem, as Áreas de Preservação Permanente (APP) são pouco respeitadas e além de forte presença de áreas degradadas, além de uma significativa área assoreada no baixo curso (desembocadura) da bacia.

\section{OBJETIVOS}

Este trabalho tem como finalidade realizar uma análise multitemporal da cobertura do uso da terra, a partir do estudo e elaboração de mapas para fins de análise e planejamento ambiental na Bacia Hidrográfica do Córrego Ribeirãozinho (BHRR). Pretendemos entender a dinâmica das classes de uso da terra no intervalo dos anos analisados. Junto a informações contidas neste trabalho e serão elaborados ainda uma série de outros trabalhos relacionados à esta temática, para que todos venham a fornecer subsídios que ao montante, possam ser aplicados e fomentado em apenas um trabalho com soluções e práticas execucionais para decisões de planejamento e manejo adequado desta mesma bacia hidrográfica.

Figura 1: Mapa Localização da Bacia Hidrográfica do Córrego Ribeirãozinho.

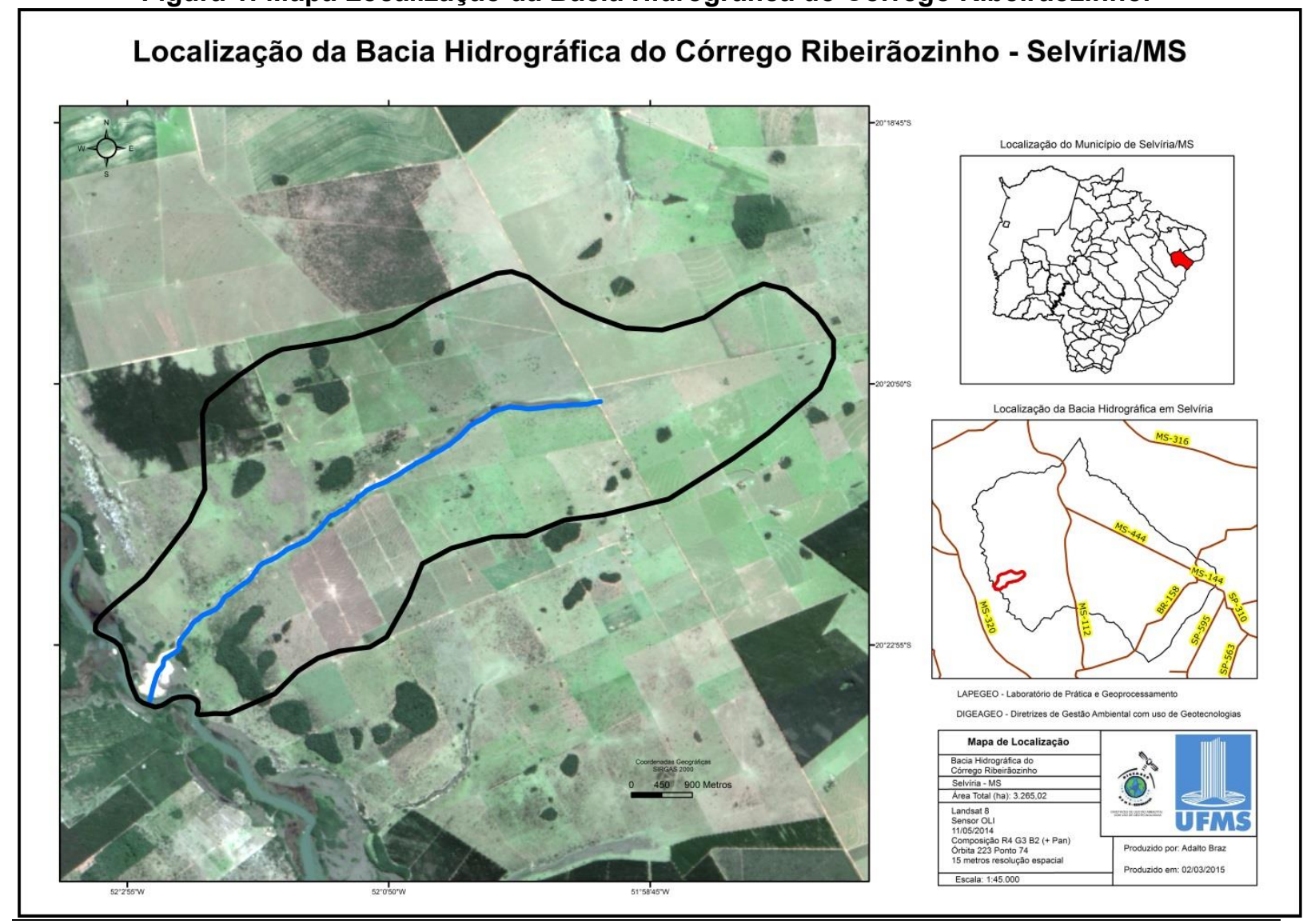


Organização e edição: BRAZ, 2015.

\section{METODOLOGIA}

A análise multitemporal do uso e ocupação da terra na bacia hidrográfica do córrego Ribeirãozinho foi realizado utilizando imagens do sensor OLI, presente no satélite Landsat 8 e sensor TM, do satélite Landsat 5 . Objetivando obter resultados e possíveis conclusões sobre a alteração do uso e ocupação da terra e a influência exercida ambientalmente na bacia.

Para tal situação foram adquiridas imagens em duas datas distintas, nos anos de 2010 e 2014. Pretendendo chegar a considerações a respeito das alterações na dinâmica da cobertura vegetal no entorno desta bacia hidrográfica.

Foi organizada uma tabela chamada comumente de chave de interpretação para a pós-classificação das imagens, para amenizar os erros ocasionados no processo de classificação de alguns pixels ou regiões das imagens. A chave de interpretação faz com que as atividades de fotointerpretação e/ou classificação das imagens de satélite ganhem certa facilidade, através do estabelecimento de padrões para cada classe previamente estabelecida para o mapeamento. Então, ao realizar a fotointerpretação, temos pré-estabelecidas formas, cores e padrões encontrados nas imagens de satélites que serão mais facilmente atribuídas às classes, evitando dúvidas e conflitos nos mapeamentos.

Tabela 1: Chave de Interpretação

\begin{tabular}{|c|l|l|}
\hline Classe & \multicolumn{1}{|c|}{$\begin{array}{c}\text { Descrição em } \\
\text { Campo }\end{array}$} & $\begin{array}{l}\text { Imagem } \\
\text { Landsat }\end{array}$ \\
\hline Pastagem & $\begin{array}{l}\text { Cor Verde/Verde } \\
\text { mesclado com Rosa } \\
\text { Textura Parcialmente } \\
\text { lisa } \\
\text { Padrão Irregular }\end{array}$ & \\
\hline $\begin{array}{c}\text { Pastagem } \\
\text { Degradada }\end{array}$ & $\begin{array}{l}\text { Cor Rosa } \\
\text { Textura Parcialmente } \\
\text { lisa } \\
\text { Padrão Irregular }\end{array}$ & \\
\hline $\begin{array}{c}\text { Vegetação Natural } \\
\text { Florestal }\end{array}$ & $\begin{array}{l}\text { Cor Verde / Verde } \\
\text { Escuro } \\
\text { Textura Rugosa } \\
\text { Padrão Irregular }\end{array}$ & \\
\hline
\end{tabular}




\begin{tabular}{|c|l|}
\hline Área Úmida & $\begin{array}{l}\text { Cor Roxo/Azul Escuro } \\
\text { Textura Parcialmente } \\
\text { lisa } \\
\text { Padrão Irregular }\end{array}$ \\
\hline Silvicultura & $\begin{array}{l}\text { Cor Verde/Verde } \\
\text { Claro } \\
\text { Textura Lisa } \\
\text { Padrão Regular }\end{array}$ \\
\hline Área Degradada & $\begin{array}{l}\text { Cor Branco/Branco } \\
\text { mesclado com Rosa } \\
\text { Textura Lisa } \\
\text { Padrão Irregular }\end{array}$ \\
\hline Água & $\begin{array}{l}\text { Cor Azul/Azul Escuro } \\
\text { Textura Lisa } \\
\text { Padrão Irregular }\end{array}$ \\
\hline \multicolumn{2}{|c|}{ Organização e edição: BRAZ, 2015 }
\end{tabular}

Para minimizar os efeitos de sazonalidade, as imagens foram obtidas em datas correspondentes a uma mesma estação do ano (inverno - estação seca), de modo em que fatores determinantes às respostas espectrais da vegetação não sofressem interferências advindas de questões naturais.

As imagens do sensor OLI correspondem a orbita 223/ponto 74, referente à data de 11/05/2014. Para a identificação e mapeamento das classes de uso da terra

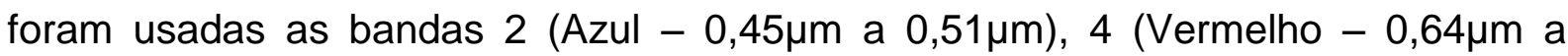

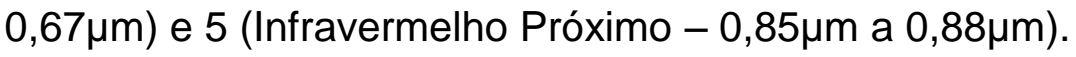

As imagens do sensor TM correspondem também à órbita 223/ponto 74 e foram imageadas na data de 17/06/2010. Para a identificação e mapeamento das

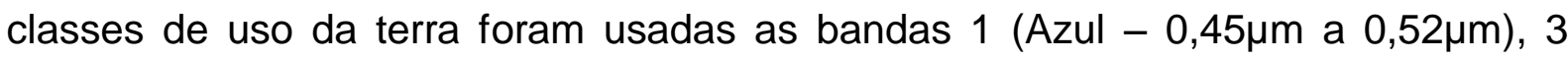

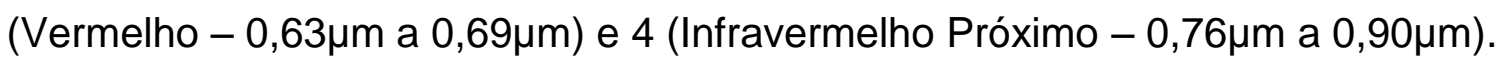

O mapeamento das classes foi feito por vetorização manual através do ArcMap, baseando-se na imagem oriunda da composição de bandas de cada sensor.

Todo o mapeamento foi concluído dentro do ambiente ArcMap e o gerenciamento do banco de dados por meio do ArcCatalog, softwares componentes do SIG ArcGIS. 


\title{
4. RESULTADOS
}

Conhecer a dinâmica e as mudanças que ocorrem na superfície terrestre, assim como a espacialização de classes importantes para meio ambiente, como vegetações, APPs, etc. são de suma importância para o entendimento do espaço estudado. É importante que se entenda, primeiramente as mudanças ocorridas no entorno de uma Bacia Hidrográfica (como aqui analisada) para que se possa entender quais motivações impulsionaram a tais modificações feitas no meio ambiente. Só após entendermos estas atividades ocorridas no espaço é que poderemos então, chegarmos a conclusões efetivas e propor medidas reais à conservação de uma bacia hidrográfica.

\begin{abstract}
O conhecimento atualizado das formas de utilização e ocupação da terra, bem como o uso histórico, tem sido um fator imprescindível ao estudo dos processos que se desenvolvem na região, tornando-se de fundamental importância na medida em que os efeitos de seu mau uso causam deterioração no meio ambiente. Os processos de erosão, desertificação, inundações, assoreamentos de cursos d'água, têm sido exemplos cotidianos do mau uso da terra (ROSA e SANO, 2014).
\end{abstract}

Ao analisar os mapas de ambos os anos (2010 e 2014) verificamos poucas mudanças no uso da terra no entorno da bacia. Mudanças mais significativas ocorrem com as áreas úmidas e áreas degradadas. A bacia do córrego Ribeirãozinho é caracterizada pela forte presença de pastagem no seu entorno. No intervalo destes quatro anos a principal classe de ocupação da terra continua sendo a pastagem. Variações com pouca significação acontecem na classe de vegetação natural florestal, com a aparente regeneração de algumas localizações dispersas. Acreditamos que as mudanças ocorridas com a dinâmica destas áreas ao longo dos anos analisados tenham sofrido pouquíssimo com a sazonalidade nas imagens.

Temos então a representação cartográfica para o uso e ocupação da terra nos anos de 2010 e 2014 nas figuras 02 e 03, respectivamente.

As principais observações a ser colocadas inicialmente quanto das mudanças ocorridas no intervalo de tempo analisado são sobre as APPs, áreas degradadas e o pasto degradado. As classes consideradas como mais frágeis nesta bacia hidrográfica são justamente as citadas acima, salvo APP que não aparece como classe de uso da terra neste estudo. Para as classes acima citadas, podemos acompanhar suas mudanças, assim como das outras classes, nos gráficos abaixo (Figura 04 e 05). 
Figura 2: Mapa de Uso e Ocupação da Terra no ano de 2010.

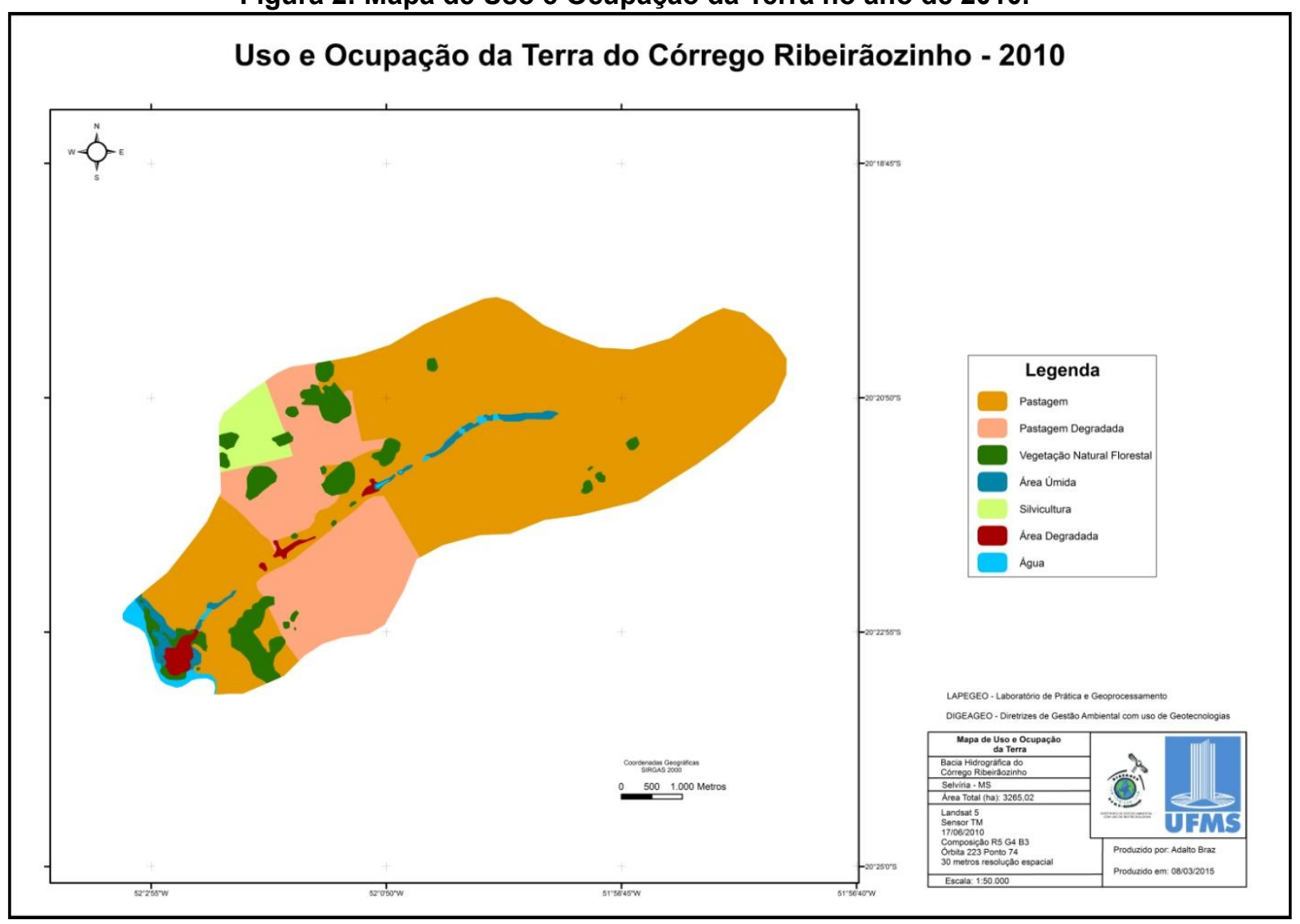

Organização e edição: BRAZ, 2015. 
Figura 3: Mapa de Uso e Ocupação da Terra no ano de 2014.

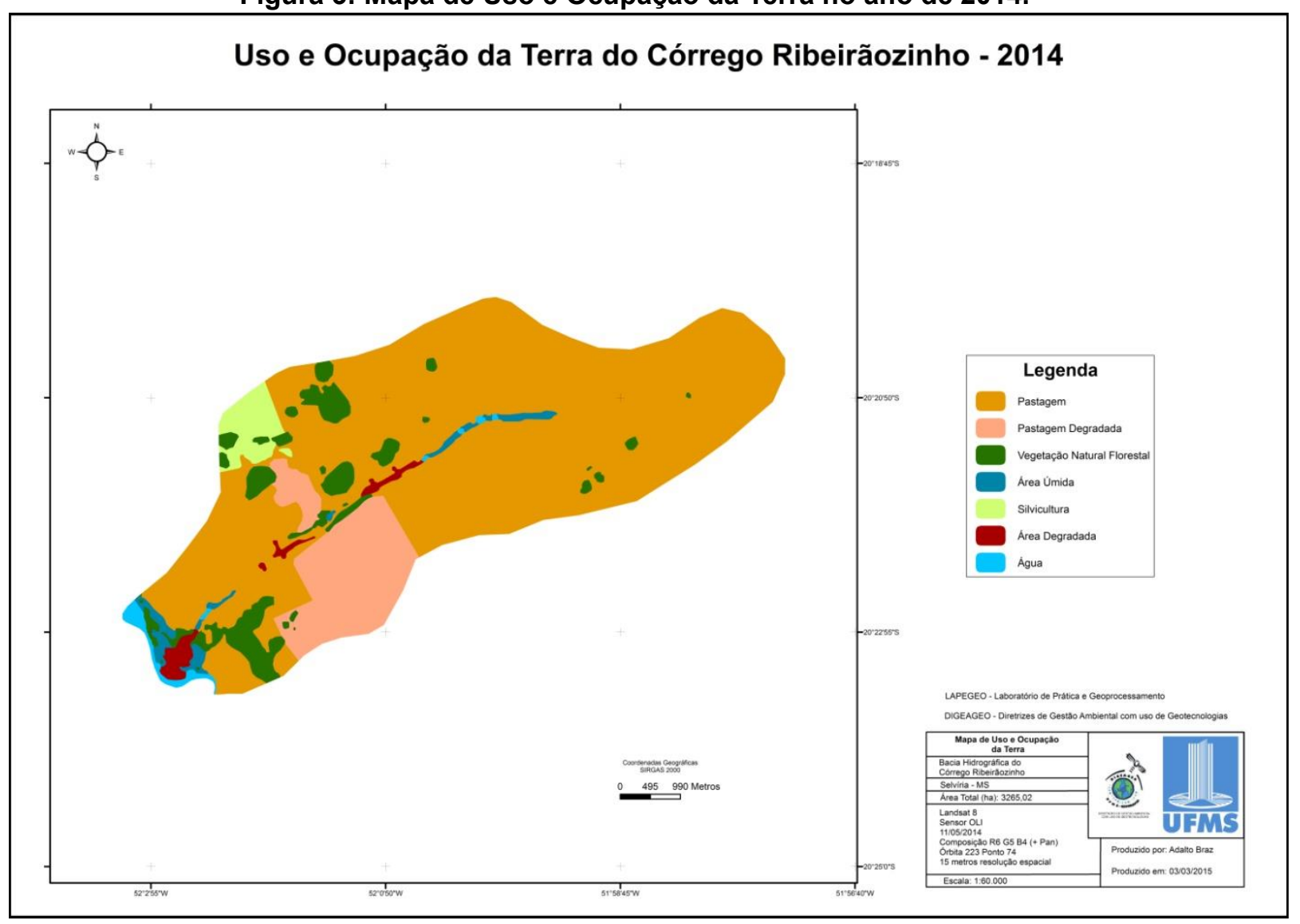

Organização e edição: BRAZ, 2015.

Temos inicialmente uma regressão das áreas consideradas como pastagem degrada, diminuindo praticamente na metade. Esta regressão é observada pela fotointerpretação, sendo que a área na margem esquerda da bacia deixa de ter um aspecto de solo exposto e passa a ter uma resposta espectral mais próxima do que é considerado como pastagem. As áreas degradadas têm um aumento de área, fato preocupante, porém já esperado, pelo fato de que em campo não é encontrado nenhum esforço para conter ou recuperar estas áreas. Apesar de não divididas nos mapeamentos, temos nas áreas degradas erosões (ravinas) e um grande leque de assoreamento na área de descarga do córrego junto ao Rio Sucuriú. 
Figura 4: Gráfico quantitativo das classes de uso e ocupação da terra - 2010

\section{Quantitavivo do Uso e Ocupação da Terra em 2010}

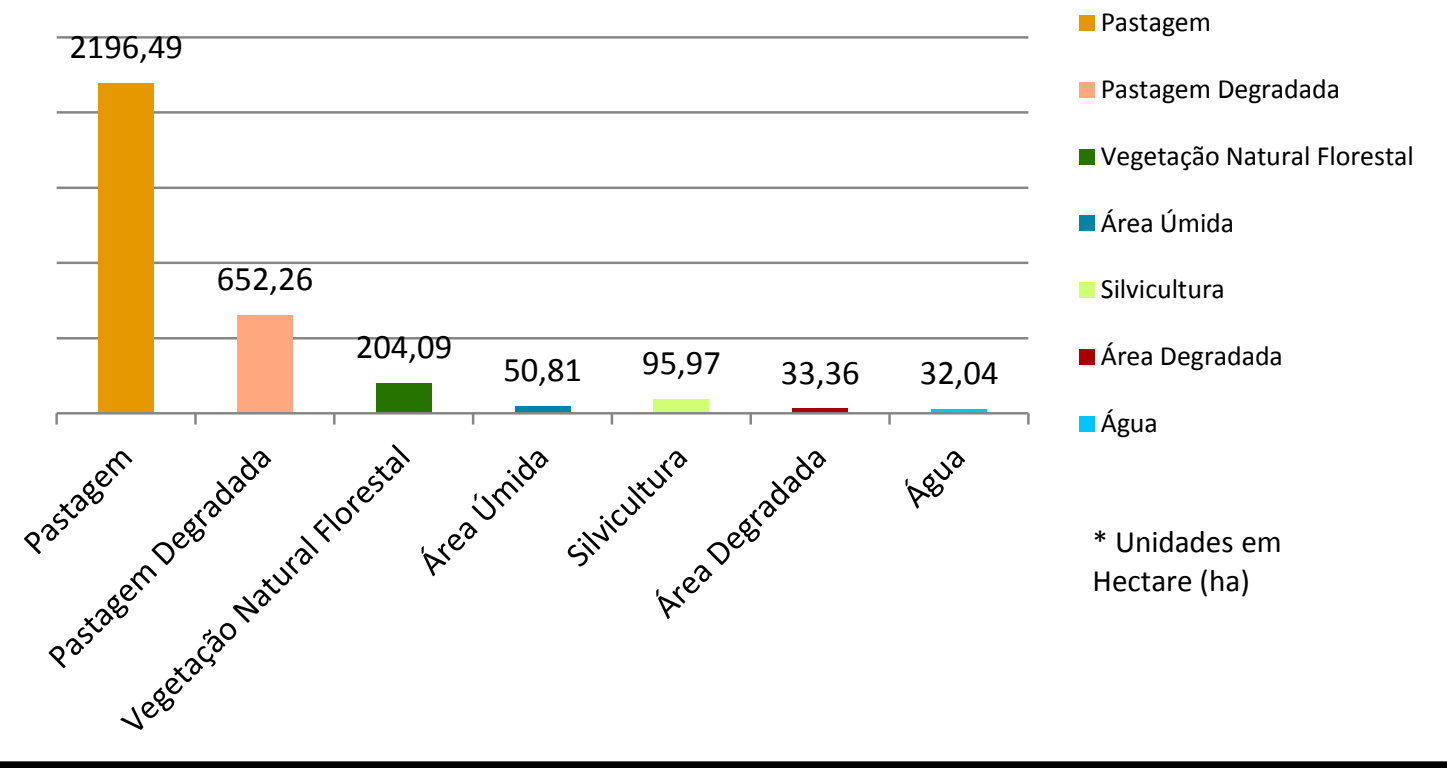

Organização e edição: BRAZ, 2015.

Figura 5: Gráfico quantitativo das classes de uso e ocupação da terra - 2014

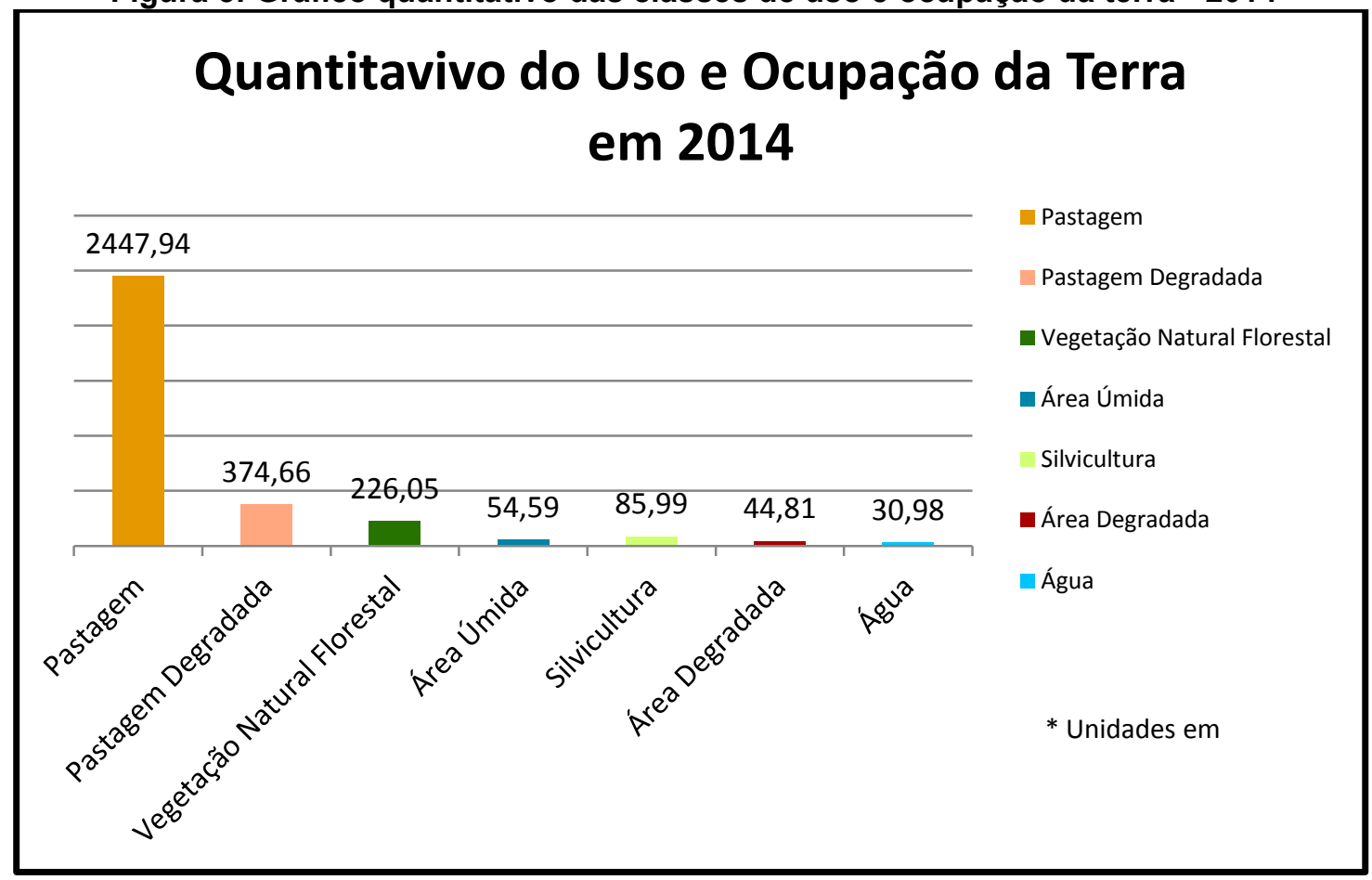

Organização e edição: BRAZ, 2015.

A paisagem encontrada ao longo da rede de drenagem não deixa dúvidas quanto ao cenário atual encontrado na bacia hidrográfica. Apesar de um aumento da área 
da classe vegetação natural florestal, surgem apenas feições dispersas, sem uma funções ambientais significativas para o ecossistema da bacia hidrográfica. De maior importância, aparece a regeneração florestal em uma curta extensão, fazendo papel de mata ciliar, na área central da rede de drenagem.

Mesmo tendo aumentado em 6 hectares o que classificou-se como área úmida (apenas varjão, já que em campo, até o momento não foram encontradas áreas de vereda), ainda não é o suficiente afirmar esse aumento de forma permanente ou benéfica. Já que estas áreas são as primeiras a tomar influências da sazonalidade climática e mesmo com algumas idas à campo, consideramos prematura a afirmação quanto a dinâmica desta classe. O que se faz necessário fixar é a falta de mata ciliar na Bacia Hidrográfica do Córrego Ribeirãozinho, ao longo de praticamente toda a rede de drenagem, e principalmente no entorno das áreas úmidas, estas que são áreas de maiores fragilidades ambientais nas bacias hidrográficas da região estudada.

As matas ciliares são vegetações que ocupam as margens dos cursos d'água, sendo elementos fundamentais na composição das APPs e preservação dos rios. Além de exercerem extrema importância para a estabilidade dos mesmos, beneficiando-os com a infiltração de água no solo e evitando que o escoamento superficial venha a degradar e/ou erodir as margens dos rios, influenciam na qualidade da água, amenizam o transporte de sedimentos (evitando assoreamento, como no caso do Córrego Ribeirãozinho), fornecem estabilidade térmica para a água, minimizam diversos outros tipos de processos erosivos e ainda servem como abrigo e alimento para a fauna aquática (LIMA e ZAKIA, 2004)

Sabendo-se das condições atuais do uso e ocupação da terra na bacia hidrográfica, visitas realizadas em campo, é claramente perceptível a falta de manejo adequado e atividades preservacionistas e mitigadoras da degradação ambiental nesta bacia. Entendemos que um dos fatores mais alarmentes nesta bacia, atualmente, é a falta de mata ciliar e preservação das APPs, além de um manejo adequado do uso da terra.

Por fim, quanto aos resultados obtidos, podemos afirmar, corroborando com Filho, Comunello e Ribeiro (2012) que o diagnóstico das condições ambientais irá fornecer o mínimo conhecimento necessário para o entendimento da dinâmica espaço-temporal do ambiente em questão. Conhecer o ambiente implica estudar o 
espaço geográfico e os aspectos ambientais nele inseridos, o que pressupõe uma série de conhecimentos e informações que podem ser trabalhados de uma maneira mais ágil, fácil e rápida com algumas das novas tecnologias hoje disponíveis.

\section{CONSIDERAÇÕES FINAIS}

O planejamento nos atende baseado em políticas, leis, diretrizes e gestão de uma determinada área. Nós Geógrafos, acreditamos que para para o planejamento ambiental de bacias hidrográficas um dos passos iniciais é o entendimento do histórico e atual uso e ocupação da terra.

Quanto a utilização dos SIGs, Junior e Mello (2012) afirmam que os SIGs são, essencialmente, suportes tecnológicos do planejamento ambiental e podem agregar agilidade, precisão e facilidade de visualização aos estudos, avaliações e simulações realizadas. O ganho em precisão e velocidade é de grande importância para a administração pública, que pode, pela utilização dos SIGs, automatizar e aumentar a eficiência de tarefas rotineiras, monótonas e consumidoras de tempo.

A intensificação do uso da terra, principalmente em seu uso para atividades agrícolas, quando não pensada e organizada dentro de diretrizes estabelecidas por um planejamento ambiental, contribui para o desencadeamento de processos erosivos. Não devemos apenas pensar no cumprimento da lei florestal, mas pensar ambientalmente nos benefícios em se preservar as nascentes e as APPs. Além da revitalização das matas ciliares e o monitoramento quando possível destas áreas (BRAZ, 2014).

Entendemos que ordenando as atividades que regem o uso e ocupação da terra em uma bacia hidrográfica, assim como o manejo adequado dos recursos naturais estaremos contribuindo para o processo de planejamento aplicado a uma bacia hidrográfica.

\section{REFERÊNCIAS BIBLIOGRÁFICAS}

ALMEIDA, A. Q. de; BERGER, B. Comparação entre áreas de preservação permanente demarcadas a partir de diferentes escalas topográficas. In: MORAIS, A. C. de; SANTOS, A. R. dos (Orgs.). Geomática \& Análise Ambiental. - Vitória, ES : EDUFES, 2007. 182 p.

ANA. O Comitê de Bacia Hidrográfica: o que é e o que faz? Agência Nacional de Águas. - Brasília: SAG, 2011.64 p.- Cadernos de capacitação em recursos hídricos; v.1. 
BRASIL. Lei no 12.651, de 25 de maio de 2012. Presidência da República. Casa Civil, Subchefia para Assuntos Jurídicos. Brasília, DF. 2012

BRAZ, A. M. Geotecnologias aplicada a análise ambiental na Bacia Hidrográfica do Córrego Carro Queimado - Três Lagoas/MS 2013. 2014. 133 p. (UFMS/CPTL). Monografia (Graduação em Geografia - Bacharelado) - Universidade Federal de Mato Grosso do Sul, Três Lagoas. 2014.

CUNHA, S. B; GUERRA, A. J. T. (Org.). A questão Ambiental: Diferentes Abordagens. $8^{a}$. ed. Rio de Janeiro: Bertrand Brasil Ltda., 2012. 250p.

CUNHA, L. H; COELHO, M. C. N. Política e gestão ambiental. p. 43-79 In: A questão Ambiental: Diferentes Abordagens. 8․․ ed. Rio de Janeiro: Bertrand Brasil Ltda., 2012

FILHO. A. S; COMUNELLO, E; RIBEIRO, A. F. do N. Geotecnologias na Caracterização EspaçoTemporal do Uso do Solo em Bacias Hidrográficas. In: SILVA, C. A. (Org.). Geografia e Natureza: experiências e abordagens de pesquisas. - Dourados : Ed. UFGD, 2012. 256 p.

FLORENZANO, T. G. Imagens de satélite para estudos ambientais. São Paulo. Oficina de textos, 2002.

FREIRE, A. P. Caracterização morfológica, hidrológica e ambiental e análise de conflito do uso do solo da bacia da lagoa Jacuném. In: MORAIS, A. C. de; SANTOS, A. R. dos (Orgs.). Geomática \& Análise Ambiental. - Vitória, ES : EDUFES, 2007. 182 p.

JUNIOR. E. M; MELLO, L. F. Mapeamento Comunitário, Percepção e Representação do Espaço: metodologias para diagnóstico e gestão ambiental. In: SILVA, C. A. (Org.). Geografia e Natureza: experiências e abordagens de pesquisas. - Dourados : Ed. UFGD, 2012. 256 p.

LIMA, W. de P. Princípios de hidrologia vegetal para o manejo de bacias hidrográficas. Piracicaba: ESALQ/USP, 1986. p.242, (Apostila).

LIMA, W. P; ZAKIA, M. J. B. Hidrologia de matas ciliares. In: RODRIGUES, R. R.; LEITÃO FILHO, H.F. Matas ciliares: conservação e recuperação. 2. ed. São Paulo: EDUSP/Fapesp, 2004. cap. 3, p. $33-44$.

ROSA, R; SANO, Edson Eyji. Uso da terra e cobertura vegetal na bacia do Rio Paranaiba. Campo - Territorio: Revista de Geografia Agrária, v. 9, p. 32-56, 2014.

Cadernos da Mata Ciliar. Secretaria de Estado do Meio Ambiente, Departamento de Proteção da Biodiversidade. - n.1 (2009) - São Paulo:SMA, 2009. 